\title{
MOLECULAR ANALYSIS OF POLYMORPHISMS IN DIFFERENTIATING Phytophthora infestans RACES
}

\section{E.A. SOKOLOVA ${ }^{1}$, E.V. MOROZOVA ${ }^{2}$, T.I. ULANOVA ${ }^{2}$, O.P. MALYCHENKO ${ }^{1,}$, Ya.I. ALEKSEEV ${ }^{1,}$, , M.A. KUZNETSOVA ${ }^{2}$, E.E. KHAVKIN ${ }^{1}$}

\begin{abstract}
${ }^{1}$ All-Russian Research Institute of Agricultural Biotechnology, Federal Agency of Scientific Organizations, 42, ul. Timiryazevskaya, Moscow, 127550 Russia, e-mail katesokol83@mail.ru, seq@syntol.ru, jalex@iab.ac.ru, emil.khavkin@gmail.com;

${ }^{2}$ All-Russian Research Institute of Phytopathology, Federal Agency of Scientific Organizations, 5, ul. Institute, pos. Bol'shie Vyazemy, Odintsovskii Region, Moscow Province, 143050 Russia, e-mail morozovela@mail.ru, ulanovatoma@mail.ru, kuznetsova@vniif.ru;

${ }^{3}$ Joint Stock Company Syntol, 42, ul. Timiryazevskaya, Moscow, 127550 Russia

Acknowledgements:

The authors are grateful to the Center for Collective Use of Equipment «Biotechnology» (All-Russian Research Institute of Agricultural Biotechnology) for sequencing Avr clones and separating SSR amplicons by capillary electrophoresis. Supported by the grants from Russian Foundation for Basic Research (projects 14-04-31613a and 16-04-00098) and the Ministry of Education and Science of the Russian Federation (project RFMEFI62114X0003). The phytopathological evaluation of Phytophthora infestans isolates was performed as part of the State Commission 0598-2015-0018. Received March 21, 2016
\end{abstract}

\section{Abstract}

Potato late blight caused by oomycete Phytophthora infestans (Mont.) de Bary is economically significant disease of worldwide importance. The traditional classification of specialized races of $P$. infestans is based on eleven resistance genes ( $R$ genes) introgressed from Solanum demissum to cultivated potato $S$. tuberosum. The selection of potato varieties, each comprising one of these $R$ genes, is referred to as the Mastenbroek-Black set of differential plants. This set has been employed to establish the virulence genes ( $r$ genes) in isolates and strains of $P$. infestans, and collections of such individual strains have been maintained as tool sets of differential races for discerning $R$ genes in cultivated and wild Solanum plants. While widely used in potato breeding for late blight resistance, these differential races have not been sufficiently explored by present-day molecular methods. We studied 11 differential races $(1 ; 3 ; 4 ; 10 ; 11 ; 1.2 ; 1.3 ; 1.4 ; 1.2 .3 ; 1.2 .4 ; 1.2 .3 .4)$ maintained in the Institute of Phytopathology for over forty years and isolate 161 possessing all 11 genes of virulence. When the differential races of $P$. infestans were genotyped with the standard set of 12 microsatellite (simple sequence repeat, SSR) loci, these races were distinct from reference Al strains and highly aggressive lines lately dominant in the Western and Central Europe. SSR clusters of differential races did not match their $r$ gene profiles. To assess the profiles of virulence genes in the differential races of $P$. infestans, we cloned three avirulence genes (Avr genes): ipiO $=A v r$-blb1, which recognizes the Rpi-blb1 $=R p i$-sto 1 gene of $S$. bulbocastanum and $S$. stoloniferum characterized by broad resistance to $P$. infestans races, and also Avr $3 a$ and Avr 4 corresponding to $R 3 a$ and $R 4$ of $S$. demissum. These Avr genes were found in all differential races under study, and each gene was represented by several alleles. The complex patterns of $A v r$ genes are in sharp contrast with the conventional concept of «simple» monogenic races. In the case of ipiO (NCBI GenBank accession numbers KP308170-KP308174, KF154431-KF154433 and KF154434-KF154439) race 1 was represented by the alleles of classes I and II, whereas races 3 and 4 comprised only the class I genes. None of three races contained the most virulent class III ipiO gene. The virulent allele $A v r 3 a_{-} E M$ was found in all investigated races, while the avirulent allele Avr3a_KI was discerned only in races 1, 3 and 1.2.3 (KF154421KF154426, KF154430, KP317568, KP317572, KP317580-KP317584, KP317588, KP317589). The Avr4 gene was cloned from differential races 1, 3, 1.4 and 11 (KF188215-KF188223). All these races contained the virulent allele, and race 11 comprised both avirulent and virulent alleles. The molecular and phytopathological evidence for Avr and $r$ genes, respectively, matched only in $30 \%$ of races. Probably, these discrepancies are due to the accumulation of mutations in the Avr genes of differential races in the course of their long-term maintenance in the collection and more complex composition of $R$ genes in plants which were initially to select the differentiating races.

Keywords: Phytophthora infestans, Avr genes, microsatellite (SSR) markers

Late blight caused by oomycete Phytophthora infestans (Mont.) de Bary 
remains one of the most significant agronomic and economic problems of potato production [1-3. Information about this disease obtained by phytopathological methods [1] have been greatly supplemented in the past two decades through the molecular studies of the pathogen and the host plant. The data about the structure of $P$. infestans and Solanum genomes have been obtained [4], transcriptome and proteomic analysis of late blight infected potato plants have been performed [5-8]. Great progress has been made in the study of virulence/avirulence genes ( $A v r$ genes) $P$. infestans and resistance genes ( $R$ genes) in wild and cultivated $S o-$ lanum forms [9-11]. Cloning of these genes gives new possibilities for the study of pathogen-host plant interactions in individual plants and agrocenoses [9, 12, 13]. Development of high resolution microsatellite analysis methods made it possible to reliably distinguish $P$. infestans isolates and lines [14]. In general, the methods of molecular genetics and biotechnology have led to considerable progress in the study of pathogenesis and breeding potato varieties resistant to late blight $[12,15,16]$.

To detect and identify $R$ genes in plants, breeders commonly use a standard set of simple and complex $P$. infestans differential races which differ in the composition of virulence factors. These factors match $R 1-R 11$ resistance genes of Solanum species responsible for the hypersensitivity reaction to the pathogen. For traditional classification of specialized $P$. infestans races a set of differential plants is commonly used comprising the potato varieties with transferred $S$. demissum $R$ genes [17-19]. Advances in molecular plant pathology made it possible to characterize $P$. infestans virulence/avirulence factors as AVR effectors, the $A v r$ gene products. Their recognition by NB-LRR receptor kinases (products of $R$ genes) induces plant protective reactions. With the lack of such recognition, effectors suppress plant immunity or change plant metabolism to provide their requirements $[9,20,21]$.

To date, polymorphic $A v r$ genes have been adequately described for their structure (including allelic polymorphism) and functional activity [9, 20, 22], but Avr gene and virulence factor matching validated in the tests with differential plants has been investigated insufficiently. According to the definition, Mastenbroek-Black differential races [18] recognize $11 S$. demissum $R$ genes only and do not identify other genes that may be present in Solanum species. However, we have demonstrated previously that simple $P$. infestans races contain several $A v r$ classes of $i p i O$ gene which recognizes $R B / R p i-b l b 1$ gene of $S$. bulbocastanum missed in $S$. demissum [23]. In addition, some differential plants contain more than one $R$ gene [24]. Currently, the difficulties have been overcome by creating a new set of «monogenic» differential plants [25], but this set has not yet become available to the majority of research and breeding laboratories.

In this study, phytopathological characterization of $P$. infestans differential races was first supplemented by the results of genotyping using molecular markers and direct analysis of virulence genes.

The objective of this research was to study the polymorphism of Phytophthora infestans differential races of various geographical origins. For this purpose, the races were studied by microsatellite analysis for 12 loci, and a comparative structural analysis was performed for three $A v r$ genes cloned after PCR amplification of $P$. infestans genomic DNA.

Technique. Phytophthora infestans samples from All-Russian Research Institute of Phytopathology (ARRIP) collection were used.

Genomic DNA was isolated from 11 simple and complex races $(1,3,4$, $10,11,1.2,1.3,1.4,1.2 .3,1.2 .4,1.2 .3 .4)$ and isolate 161 which had all 11 virulence genes, using AxyPrep ${ }^{\mathrm{TM}}$ Multisource Genomic DNA Miniprep Kit (Axygen 
Biosciences, USA). DNA concentration was measured by an UV/Vis NanoPhotometer P300 (IMPLEN, Germany).

Primers for $A v r$ amplification were synthesized by ZAO Synthol (Russia). PCR reaction mixture contained $1 \mu$ l of $10 \times$ PCR buffer, 100-150 ng of genomic DNA, $1 \mu \mathrm{l}$ of $2.5 \mathrm{M}$ dNTP, $10 \mathrm{pmol}$ of each primer, 1 unit of Pfu DNA polymerase (Fermentas, Lithuania) for cloning or Taq DNA polymerases (ZAO Synthol, Russia) for screening, and sterile water to a volume of $10 \mu \mathrm{l}$. Amplification was performed in a MJ PTC-200 thermal cycler (Bio-Rad, USA) using the programs described above [23, 27-29].

PCR products were separated by electrophoresis in $1 \%$ agarose gel with buffer supplemented with ethidium bromide. Amplified DNA fragments were excised from the gel under UV and purified using QIAquick Gel Extraction reagent kit (Qiagen N.V., Germany) according to the manufacturer's protocol. Cloning was performed in pGEM/T Vector (Pro-mega, CШA). Isolated plasmids were sequenced using a NANOFOR 05 analyzer (Institute for Analytical Instrumentation RAS, Russia). Nucleotide sequences of the three $A v r$ genes were deposited at GenBank NCBI (National Center for Biotechnology Information, USA) and compared with other sequences stored.

For $P$. infestans genotyping 12 microsatellite (simple sequence repeats, SSR) markers were used [14, 26]. The protocol of amplicon length analysis and standardization has been described previously [30].

Results. $P$. infestans differential races are shown in Table 1, and primers used for $A v r$ amplification are shown in Table 2.

1. Phytophthora infestans differential races used in the study (collection of All-Russian Research Institute of Phytopathology, Moscow Province)

\begin{tabular}{l|l|c|c|c}
\hline Isolate & Origin & $\begin{array}{c}\text { Virulence } \\
\text { factor }\end{array}$ & $\begin{array}{l}\text { Matching } \\
\text { type }\end{array}$ & $\begin{array}{l}\text { Year of } \\
\text { isolatoion }\end{array}$ \\
\hline $2 \mathrm{~K}$ & Germany & 1 & $\mathrm{~A} 1$ & 1970 \\
$4 \mathrm{~K}$ & Germany & 3 & $\mathrm{~A} 1$ & 1970 \\
$5 \mathrm{~K}$ & Germany & 4 & $\mathrm{~A} 1$ & 1970 \\
$6 \mathrm{~K}$ & Georgia & 10 & $\mathrm{~A} 1$ & 1978 \\
$7 \mathrm{~K}$ & Georgia & 11 & $\mathrm{~A} 1$ & 1978 \\
$8 \mathrm{~K}$ & Germany & 1.2 & $\mathrm{~A} 1$ & 1970 \\
$9 \mathrm{~K}$ & Germany & 1.3 & $\mathrm{~A} 1$ & 1970 \\
$10 \mathrm{~K}$ & Germany & 1.4 & $\mathrm{~A} 1$ & 1970 \\
$14 \mathrm{~K}$ & Russia & 1.2 .3 & $\mathrm{~A} 1$ & 1974 \\
$15 \mathrm{~K}$ & Russia & 1.2 .4 & $\mathrm{~A} 1$ & 1974 \\
$18 \mathrm{~K}$ & Germany & 1.2 .3 .4 & $\mathrm{~A} 1$ & 1970 \\
161 & Russia (Moscow & & & \\
& Province) & $1-11$ & $\mathrm{~A} 1$ & 2010 \\
\hline
\end{tabular}

Genes Avr3a, Avr4, and $i p i O$ were found in all $P$. infestans isolates studied. These results confirm our previous data [23] and suggest a more complex composition of isolate $A v r$ genes compared to the traditional ideas of «simple» races.

A large number of Avr alleles complicates creating highly specific SCAR (sequence characterized amplified region) markers for screening $P$. infestans isolates to characterize the pathogen in the early stages of infection. Full-length $A v r$ sequences have to be amplified using conserved primers, and then clone the amplicons obtained. We found a significant polymorphism in the three $A v r$ genes studied.

2. Sequences of primers used for Avr amplification in Phytophthora infestans differential races

\begin{tabular}{|c|c|c|c|c|}
\hline Gene & $5^{\prime} \rightarrow 3^{\prime}$ sequence of primers & \begin{tabular}{|l|} 
Annealing \\
temperature, ${ }^{\circ} \mathrm{C}$
\end{tabular} & $\begin{array}{l}\text { Amplicon } \\
\text { length, bp }\end{array}$ & Reference \\
\hline$\overline{\text { ipiO }}$ & $\begin{array}{l}F-\text { CTTTCCGGCAATGCGTTCGC } \\
R-\text { CTATACGATGTCATAGCATGACAC }\end{array}$ & 65 & 510 & $(23,27)$ \\
\hline$A v r 3 a$ & $\begin{array}{l}\mathrm{F} \text { - CCATGCGTCTGGCAATTATGCT } \\
\mathrm{R} \text { - CTGAAAACTAATATCCAGTGA }\end{array}$ & 61 & 451 & (28) \\
\hline Avr4 & $\begin{array}{l}\mathrm{F} \text { - ATGCGTTCGCTTCACATTTTGCTGG } \\
\mathrm{R} \text { - CTAAGATATGGGCCGTCTAGCTTGGAG }\end{array}$ & 61 & 864 & (29) \\
\hline
\end{tabular}

Gene ipiO $=A v r$-blb1 had the most significant polymorphism recog- 
nized by $S$. bulbocastanum $R B / R p i$-blb1 resistance gene and its ortholog Rpisto 1 in S. stoloniferum [9]. Frequent Avr occurrence in P. infestans gives Solanum and potato varieties carrying $R B / R p i-b l b 1$ and $R p i$-stol resistance to most pathogen races. Gene ipiO was represented by three polymorphic classes. In experiments on transient ipiO and Rpi-blb1 co-expression in Nicotiana benthamiana plants, class I alleles ipiO were shown to be recognized by Rpi-blb1 and, therefore, were avirulent. Genes from class II were also virulent, but in the absence of class I genes only. Alleles ipiO of the rarer class III did not interact with the $R p i-b l b 1$ and were virulent [9].

In our experiments, ipiO was cloned and sequenced from simple races 1 , 3 , and 4 . In race 1 , we found substitutions typical of class I and II ipiO genes. Races 3 and 4 had no class II ipiO genes. None of the isolates studied had ipiO genes of the most virulent class III (Table 3). Therefore, races 1,3 , and 4 should be avirulent on the plants carrying $R B / R p i-b l b 1$ and Rpi-sto 1 .

3. Virulence classes of ipiO identified in simple Phytophthora infestans differential races (collection of All-Russian Research Institute of Phytopathology, Moscow region)

\begin{tabular}{|c|c|c|c|c|c|c|c|c|c|}
\hline \multirow{2}{*}{ Race } & \multicolumn{7}{|c|}{ Class I } & \multirow{2}{*}{\begin{tabular}{|c|} 
Class II \\
ipiO-03-13
\end{tabular}} & \multirow{2}{*}{$\begin{array}{l}\text { NCBI GenBank } \\
\text { accession number }\end{array}$} \\
\hline & ipiO-01 & ipiO-06 & ipiO-08 & ipiO-09 & ipiO-10 & ipiO-11 & ipiO-12 & & \\
\hline 1 & + & - & - & + & - & - & + & + & KP308170-KР308174 \\
\hline 3 & + & - & - & - & - & + & - & - & KF154431-KF154433 \\
\hline 4 & + & - & - & - & + & - & - & - & KF154434- KF154439 \\
\hline Note & «+» и «- & $\rightarrow-$ varia & nt presenc & ce or absen & ice, respec & ctively. & & & \\
\hline
\end{tabular}

$A v r 3 a$ was represented by two most common forms: Avr3a_KI, the avirulence allele recognized by R3a kinase, and $A v r 3 a \_E M$, the virulence allele not recognized by this kinase. Effectors matching two alleles Avr3a differed in three amino acid residues. C19, K80, and $\mathrm{I} 103$ amino acid residues are typical of avirulence allele $A v r 3 a \_K I$, while S19, E80, and M103 are typical of virulence allele $A v r 3 a \_E M$ [28].

$A v r 3 a$ was cloned from races $1,1.2,1.3,1.2 .3,1.2 .4,3,4,10,11$, and 1.2.3.4 and sequenced (Table 4). In this, we found virulence allele $A v r 3 a \_E M$ in all races studied, whereas the haplotype identical to avirulence allele $A v r 3 \bar{a} \_K I$ was found in races 1,3 , and 1.2.3 only. In addition, inactive paralog PEX147-2 was found in race 1 . It is noteworthy that in three races only $(1,1.3,1.2 .3 .4)$ allele composition matched the composition off virulence genes which was determined based on the earlier phytopathological analysis with differential plants (see Table 4). Several races contained not previously described Avr3a alleles.

4. Avr3a allelic diversity in Phytophthora infestans simple differential races (collection of All-Russian Research Institute of Phytopathology, Moscow region)

\begin{tabular}{|c|c|c|c|c|}
\hline \multirow{2}{*}{ Race } & \multirow{2}{*}{$\begin{array}{l}\text { Expected } A V R 3 a \\
\text { genotype }\end{array}$} & \multicolumn{2}{|c|}{ Allele $A v r 3 a$ (molecular data) } & \multirow{2}{*}{$\begin{array}{l}\text { NCBI GenBank accession } \\
\text { number }\end{array}$} \\
\hline & & Avr3a_KI (avirulence) & $A v r 3 a \_E M$ (virulence) & \\
\hline $\mathrm{1e}^{\mathrm{e}}$ & Avr $3 a K I$ & + & + & KF154421, KP317568- KP317572 \\
\hline 3 & Avr3a_EM & + & + & \\
\hline 4 & Avr3a_KI & - & + & \\
\hline 1.2 & Avr3a_KI & - & + & KF154422, KF154423 \\
\hline $1.3^{\mathrm{e}}$ & Avr3a_EM & - & + & KF154424, KF154425 \\
\hline 1.2 .3 & Avr3a_EM & + & + & KF154426-KF154429 \\
\hline 1.2 .4 & Avr $3 a_{-}^{-} K I$ & - & + & KF154430 \\
\hline 10 & Avr3a_KI & - & + & КР317580-КР317584 \\
\hline 11 & Avr3a_KI & - & + & \\
\hline $1.2 .3 .4^{\mathrm{e}}$ & $A v r 3 a-E M$ & - & + & KP317588, KР317589 \\
\hline
\end{tabular}

Avr4 was cloned from races 1, 3, 1.4, and 11 (GenBank KF188215KF188223 accession numbers) and sequenced. For Avr4, virulence allele was different from avirulence one in the reading frame failure and the presence of stop codons 


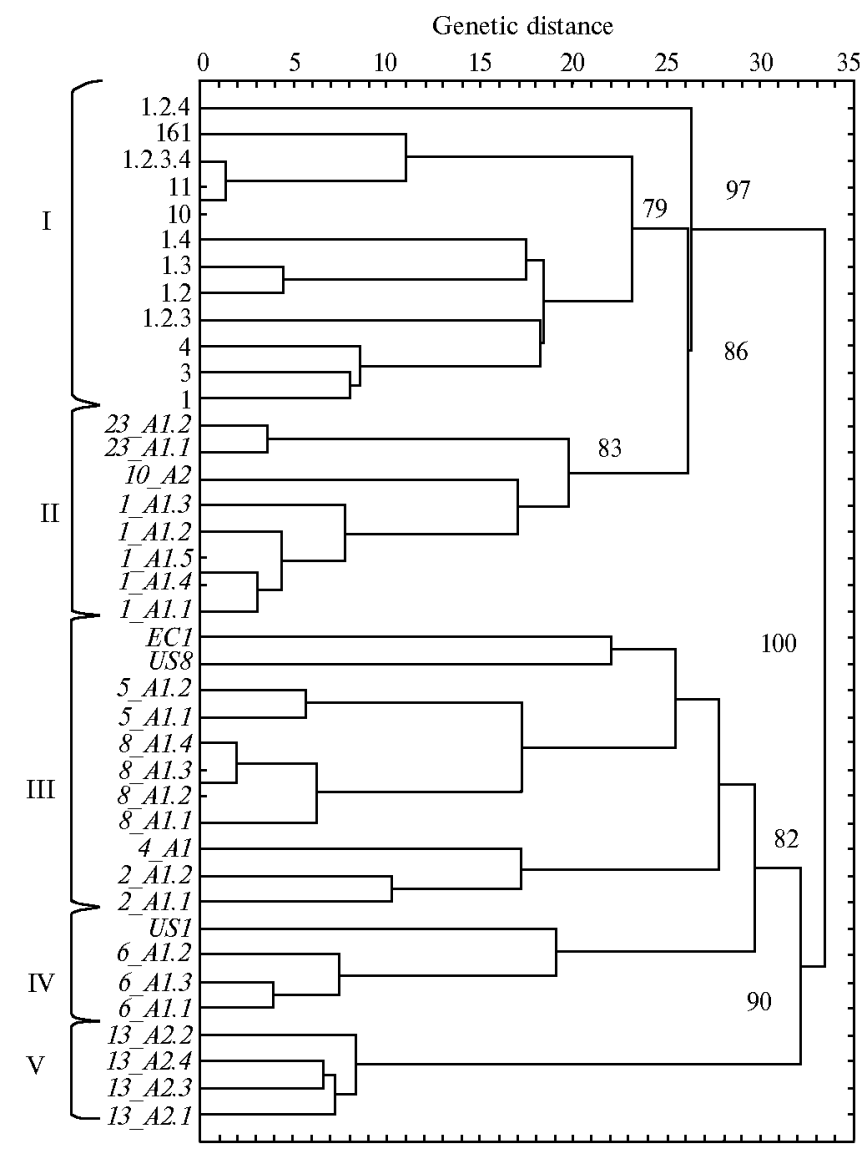

Fig. 1. Dendrogram based on differential race and reference isolate Phytophthora infestans genotyping for 12 microsatellite loci $[14,26]$ : cluster I - differential races, clusters II-V - reference strains (Neighbor Joining method; bootstrap values for 1000 repetitions exceeding 0.70 are shown).

A full length protein can not be translated from virulence Avr4 nucleotide sequence. We found this allele in all races studied. Both Avr4 alleles were found in race 11. The results for the races 11 and 1.4 only were consistent with the phytopathologically based hypothesis of the presence of avirulence allele $A v r 4$ in the genomes of the races in the names of which figure 4 is absent, and vice versa.

In potato varieties' genotyping by phytopathological methods to

determine $R 1-R 11$ composition in $S$. demissum, the variety infected by a certain race is assumed to contain $R$ gene (or genes) matching the race number strictly. Races for genotyping (simple races) are selected on differential plants (plants with a known set of $R$ genes). A discrepancy between the molecular and phytopathological data can be due to a change in the set of active $A v r$ genes in $P$. infestans simple races during their long-term maintenance in the collection and to a more complex composition of $R$ genes in differential plants than previously thought [24].

We performed phylogenetic analysis of our results (Fig. 1) comparing previously published data on the allelic composition of the same loci in standard genotypes $U S 1-A 1, E C 1 \_A 1$, and $U S 8-A 2$, several Western European reference A1 lines and recently emerging highly aggressive clones $13 \_A 2$ and 6_A1 [14, 26] (Fig. 1).

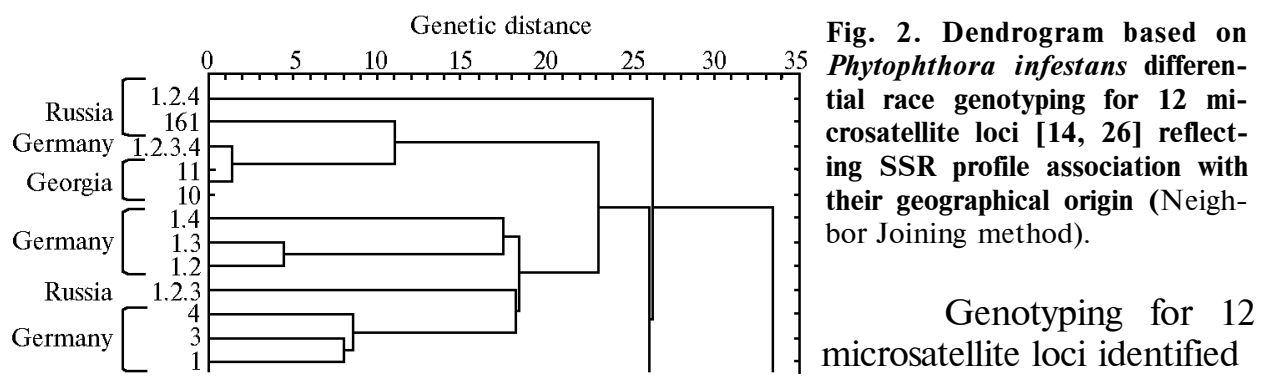


notable differences between differential races and all lines from the Western Europe $[14,26]$. Interestingly, differential race subclusters matched the geographical origin of these races partially (Fig. 2).

Thus, we were the first to define the profile of virulence genes in Phytophthora infestans differential races using molecular techniques. These races appeared to have more complex $A v r$ allelic composition than previously thought. They all contained active ipiO genes, and $A v r 3 a$ and $A v r 4$ virulence alleles. The presence of avirulence alleles $A v r$ that match $r$ genes identified by the phytopathological method (with differential plants) not always was in line with expected results. Probably, the discrepancies in the molecular and phytopathological data on the composition of virulence genes were due to the accumulation of mutations in $A v r$ genes in the course of long-term maintenance of differential races in the collection, and more complex composition of $R$ genes in differential plants initially used to select these races. Genotyping for 12 microsatellite loci identified notable differences between differential races and reference isolates from Western Europe. This may be due to the fact that differential races have been maintained in the collection since 1970s and may be significantly distinct from the modern pathogen isolates. Microsatellite profiles of differential races were not associated with the profiles of virulence/avirulence genes.

\section{REFEREN C ES}

1. Fry W.E. Phytophthora infestans, the crop (and $R$ gene) destroyer. Mol. Plant Pathol., 2008, 9(3): 385-402 (doi: 10.1111/j.1364-3703.2007.00465.x).

2. Haverkort A.J., Boonekamp P.M., Hutten R., Jacobsen E., Lotz A.P., Ke s s e 1 G.J., Vis s e r R.G., va n d e r Vos s e $n$ E.A. Societal costs of late blight in potato and prospects of durable resistance through cisgenic modification. Potato Res., 2008, 51(1): 4757 (doi: 10.1007/s11540-008-9089-y).

3. Haverkort A.J., B oonekamp P.M., Hutten R., J a cobsen E., Lotz L.A.P., Kesse 1 G.J.T., Voss e $n$ J.H., Viss e $r$ R.G.F. Durable late blight resistance in potato through dynamic varieties obtained by cisgenesis: Scientific and societal advances in the DuRPh project. Potato Res., 2016, 59(1): 35-66 (doi: 10.1007/s11540-015-9312-6).

4. Visser R.G.F., Bachem C.W.B., Borm T., de Boer J., van Eck H.J., Finkers R., van der Linden C., Maliepaard C.A., Uitdewilligen J.G.A.M.L., Voor rips R., Vos P., Wolters A.M.A. Possibilities and challenges of the potato genome sequence. Potato Res., 2014, 57(3): 327-330 (doi: 10.1007/s11540-015-9282-8).

5. Gyetvai G., Sønderkær M., Göbel U., Basekow R., Ballvora A., I m hoff M., Ke rste n B., Nielse n K.-L., G eb hardt C. The transcriptome of compatible and incompatible interactions of potato (Solanum tuberosum) with Phytophthora infestans revealed by DeepSAGE analysis. PLoS One, 2012, 7(2): e31526 (doi: 10.1371/journal.pone.0031526).

6. Jupe F., Witek K., Verweij W., Sliwka J., Pritchard L., Etherington G.J., M a c le a n D., C o ck P.J., Legget t R.M., B ryan G.J., Cardle L., He in I., J o n e s J.D.G. Resistance gene enrichment sequencing (RenSeq) enables reannotation of the NB-LRR gene family from sequenced plant genomes and rapid mapping of resistance loci in segregating populations. Plant J., 2013, 76(3): 530-544 (doi: 10.1111/tpj.12307).

7. G a o L., T u Z.J., M i 11 e t t B.P., B rade e $\mathrm{n}$ J.M. Insights into organ-specific pathogen defense responses in plants: RNA-seq analysis of potato tuber-Phytophthora infestans interactions. BMC Genomics, 2013, 14: 340 (doi: 10.1186/1471-2164-14-340).

8. Seidl M.F., Schneider A., Gover F., Snel B. A predicted functional gene network for the plant pathogen Phytophthora infestans as a framework for genomic biology. BMC $G e$ nomics, 2013, 14(1): 483 (doi: 10.1186/1471-2164-14-483).

9. Vleeshouwers V.G.A.A., R affae le S., Vossen J., Champouret N., Oliva R., S e gre ti n M.E., Ri e t man H., C a no L.M., Lo kos sou A., Ke s s e 1 G., P e 1 M.A., $\mathrm{K}$ a m o u n S. Understanding and exploiting late blight resistance in the age of effectors. Annu. Rev. Phytopathol., 2011, 49: 507-531 (doi: 10.1146/annurev-phyto-072910-095326).

10. Rodewald J., Trognitz B. Solanum resistance genes against Phytophthora infestans and their corresponding avirulence genes. Mol. Plant Pathol., 2013, 14(7): 740-757 (doi: 10.1111/mpp.12036).

11. Vos s e n J.H., Jo K.R., Vos man B. Mining the genus Solanum for increasing disease resistance. In: Genomics of plant genetic resources. R. Tuberosa, A. Graner, E. Frison (eds.). 
Springer, Netherlands, Dordrecht, 2014: 27-46 (doi: 10.1007/978-94-007-7575-6_2).

12. Fawke S., Doum a n e M., S chornack S. Oomycete interactions with plants: infection strategies and resistance principles. Microbiol. Mol. Biol. Rev., 2015, 79(3): 263-280 (doi: 10.1128/MMBR.00010-15).

13. Mariette N., Mabon R., Corbiere R., Boulard F., Glais I., Marquer B., Pasco C., Montarry J., Andrivon D. Phenotypic and genotypic changes in French populations of Phytophthora infestans: are invasive clones the most aggressive? Plant Pathol., 2016, 65(4): 577-586 (doi: 10.1111/ppa.12441).

14. Li Y., Cooke D.E., Jacobsen E., van der Le e T. Efficient multiplex simple sequence repeat genotyping of the oomycete plant pathogen Phytophthora infestans. J. Microbiol. Meth., 2013, 92(3): 316-322 (doi: 10.1016/j.mimet.2012.11.021).

15. Halterman D., Guenthner J., Collinge S., Butler N., Douches D. Biotech potatoes in the 21st century: 20 years since the first biotech potato. Am. J. Potato Res., 2016, 93(1): 1-20 (doi: 10.1007/s12230-015-9485-1).

16. Hogenhout S.A., Van der Hoorn R.A., Terauchi R., Ka moun S. Emerging concepts in effector biology of plant-associated organisms. Mol. Plant-Microbe Interact., 2009, 22(2): 115-122 (doi: 10.1094/MPMI-22-2-0115).

17. B la ck W., M a ste nbroek C., Mills W.R., Peterson L.C. A proposal for an international nomenclature of races of Phytophthora infestans and of genes controlling immunity in Solanum demissum derivatives. Euphytica, 1953, 2(3): 173-179 (doi: 10.1007/BF00053724).

18. M a lc olm s o n J.F., B la ck W. New $R$ genes in Solanum demissum Lindl. and their complementary races of Phytophthora infestans (Mont.) de Bary. Euphytica, 1966, 15(2): 199-203 (doi: 10.1007/BF00022324).

19. Bradshaw J.E. Potato breeding at the Scottish Plant Breeding Station and the Scottish Crop Research Institute: 1920-2008. Potato Research, 2009, 52(2): 141-172 (doi: 10.1007/s11540-009-9126-5).

20. B ouw meester K., van Poppel P., Govers F. Genome biology cracks enigmas of oomycete plant pathogens. In: Molecular aspects of plant disease resistance. UK, Oxford, WileyBlackwell, 2009, 102-134 (doi: 10.1111/b.9781405175326.2009.00005.x).

21. Win J., Chaparro-Garcia A., B e 1 haj K., S a unders D.G.O., Yoshida K., Dong S., Schornack S., Zipfel C., Robatzek S., Hogenhout S.A., Kam o u n S. Effector biology of plant-associated organisms: concepts and perspectives. Cold Spring Harbor Symposia on Quantitative Biology, 2012, 77: 235-247 (doi: 10.1101/sqb.2012.77.015933).

22. $\mathrm{R}$ i e t $\mathrm{m}$ a $\mathrm{n} \mathrm{H}$. Putting the Phytophthora infestans genome sequence at work; multiple novel avirulence and potato resistance gene candidates revealed. PhD thesis. Wageningen, The Netherlands, Wageningen University, 2011. Available: http://library.wur.nl/WebQuery/wurpubs/406778 [Accessed 31 May 2016].

23. Pankin A., Kinash E., Rogozina E., Kozlovskaya I., Kuznetsova M., $\mathrm{K}$ h avkin E. Are simple Phytophthora infestans races that simple? In: PPO-Special Report no. 15. H.T.A.M. Schepers (ed.). DLO Foundation, Wageningen, 2012: 205-211. Available: http://130.226.173.223/euroblight/Workshop/2011StPetersburg/Proceedings/Page205-212_ArtemPankin_web.pdf [Accessed 31 May 2016].

24. K i m H.-J., Le e H.-R., J o K.-R., Mortazavi a n S.M.M., H u ige n D.J., Eve $\mathrm{nh}$ u is B., Ke s s e 1 G., V is s e r R.G.F., J a c ob s e n E., V o s s e n J.H. Broad spectrum late blight resistance in potato differential set plants $\mathrm{Ma} R 8$ and $\mathrm{Ma} R 9$ is conferred by multiple stacked $R$ genes. Theor. Appl. Genet., 2012, 124(5): 923-935 (doi: 10.1007/s00122-011-1757-7).

25. Zhu S., Vossen J.H., Bergervoet M., Nijenhuis M., Kodde L., Kesse 1 G.J.T., Vle es houwers V., Visser R.G.F., Jacobsen E. An updated conventional-and a novel GM potato late blight $R$ gene differential set for virulence monitoring of Phytophthora infestans. Euphytica, 2015, 202(2): 219-234 (doi: 10.1007/s10681-014-1276-0).

26. Cooke D., Cano L., Raffaele S., Bain R., Cooke L., Etherington G.J., D e a h 1 K.L., Farrer R.A., Gilroy E.M., Goss E.M., Grünwald N.J., He in I., Mac Lean D., McNicol J.W., Randall E., Oliva R.F., Pel M.A., Shaw D.S., S quires J.N., Taylor M.C., Vle es houwe rs V.G., B i rch P.R., Le es A.K., $\mathrm{K}$ a m o u n S. Genome analyses of an aggressive and invasive lineage of the Irish potato famine pathogen. PLoS Pathog., 2012, 8(10): e1002940 (doi: 10.1371/journal.ppat.1002940).

27. Champouret N., Bouwmeester K., Rietman H., van der Lee T., Maliepaard C., Heupink A., van de Vondervoort P.J.I., Jacobsen E., Vis s e r R.G.F., van d e r Vos sen E.A.G., Govers F., Vle e s houw e rs V.G.A.A. Phytophthora infestans isolates lacking class 1 ipio variants are virulent on Rpi-blb1 potato. Mol. Plant-Microbe Interact., 2009, 22(12): 1535-1545 (doi: 10.1094/MPMI-22-12-1535).

28. Armstrong M.R., Whisson S.C., Pritchard L., Bos J.I.B., Venter E., Avrova A.O., Rehmany A.P., Böhme U., Brooks K., Cherevach I., Ha m lin N., White B., Fraser A., Lord A., Quail M.A., Churcher C., Hall N., Berri ma n M., Huang S., Ka moun S., B e y n o n J.L., B i r ch P.R.J. An ancestral oomy- 
cete locus contains late blight avirulence gene $A v r 3 a$, encoding a protein that is recognised in the host cytoplasm. PNAS USA, 2005, 102(21): 7766-7771 (doi: 10.1073/pnas.0500113102).

29. van Poppel P.M.J.A., Guo J., van de Vondervoort P.J.I., Jung M.W.M., B i rch P.R.J., Whisson S.C., Govers F. The Phytophthora infestans avirulence gene Avr4 encodes an RXLR-dEER effector. Mol. Plant-Microbe Interact., 2008, 21(11): 1460-1470 (doi: 10.1094/MPMI-21-11-1460).

30. Kuznetsova M.A., Kozlovski i B.E., Beketova M.P., Sokolova E.A., Ma 1y u chenko O.P., A l e ks e v Ya.I., Rogozina E.V., Khavkin E.E. Mikologiya $i$ fitopatologiya, 2016, 50(3): 175-184 (in Russ.). 